\title{
Correspondence
}

\section{National Counctl of Social Workers with the Deaf}

DEAR SIR

I have been in correspondence with the National Counci of Social Workers with the Deaf which is anxious to publicize the names and addresses of branch secretaries who could act as points of contact where assistance is required in connection with prelingually deaf patients. In many areas contact is already well established but this is not so every. where, and branch secretaries are able to advise whether or not a specialist social worker with the deaf is available in a particular area. I enclose a list of names and addresses indicating where assistance can be obtained by psychiatrists when they have to deal with a deaf patient.

National Secretary: Mrs V. Conway, The Vicarage, Fron Park Road, Holywell, Clwyd

Northern Counties: Mr R. S. Pringle, Social Services Department, Windmill Hills, Gateshead, NE8 1PJ

North West: Mr I. Kershaw, Centre for the Deaf, 32-40 Denton Green Lane, St. Helens

Yorkshire \& Humberside: The Rev R. Bell, Social Services Department, Orchard House, Orchard Street, Lincoln

Midlands: Mrs S. Grew, Social Services Department, Civic Centre, Darwall Street, Walsall WSI IRG

South East: Mr C. Palmer, Social Services Department, 17-23 Clements Road, Ilford, Essex 1G1 1BL

South West: The Rev M. Sabell, Centre for the Deaf, 18 Augustine Road, Southampton

Ireland: Mrs M. Breen, Social Services Office, Waterside Hospital Grounds, Londonderry

Scotland: Mrs. L. Grant, Centre for the Deaf, 36 Roseangle, Dundee

Wales: Mr K. Butterfield, Social Services Department, Cunlifie House, Rhosodu Road, Wrexham, Clwyd

All Saints Hospital

ROBERT BLUGLASS

Lodge Road

Birmingham B18 SSD

\section{Representing the mentally ill and handicapped}

DEAR SIR

It appears fashionable these days to make generalized attacks on MIND, which are notable only for their overstatement and disinterest in the details of MIND policy. I would not have expected a person of the usual fairness of $\mathrm{Dr}$ John Hamilton to join on an unconstructive and highly emotional bandwagon in his review of Representing the Mentally IIl and Handicapped (Bulletin, December 1980).

Dr Hamilton is apparently wholly opposed to the idea of effective representation as set out in the book and recommends it to psychiatrists on the principle of 'know thine enemy'. Dr Hamilton's view is not shared by those organizations and individuals who are responsible for the provision of legal, health and social services to psychiatric patients. MIND and the Law Society are implementing the principle of effective representation put forward in the book in a pilot project in the Oxford Region. The project has received support from, inter alios, the Secretary of State, the Royal College of Psychiatrists, the Association of Social Services Directors, the Probation Service, and the Council on Tribunals. Indeed, Dr Hamilton's own hospital, Broadmoor, has been constructive and cooperative, encouraging independent research into the area. This kind of support suggests that Dr Hamilton's admonition 'know thine enemy' is a highly personalized view; I hope Members of the College will bear this in mind when considering the merits of the review. Representing the Mentally III and Handicapped (partly funded by the DHSS) was based upon four years experience in operating a tribunal representation service for patients; it was widely welcomed in legal and academic circles as the only serious and comprehensive review of the law and practice of tribunals since their inception in 1960.

I should like to examine what I consider to be the logical errors in the review. It begins by a quote from Edmund Burke in 1774 about the political representation of Members of Parliament. This analogy could not be more inapposite to legal representation in the 1980 s. The legal profession has standards of representation for individual clients which are qualitatively different from those of Members of Parliament who are representatives for their entire constituencies. I don't believe any right-minded individual would want his lawyer to represent him in court or before a tribunal in the same way his MP represents him in Parliament. The legal representative is directly accountable to his client while the MP has a large number of competing interests to follow which may subordinate the interests of any individual constituent.

The source of a representative's authority derives from the client; the representative is intended to speak on behalf of the client and not according to his own personal views of the merits of a case. It is not the role of the representative to make 'best interests' judgments. He does not have the expertise and experience in clinical and social matters to make such judgments. Moreover, even if he were capable, any decision would pre-judge the result of the case. The 